\title{
Conceptual Framework of Combined Pixel and Object-based Method for Delineation of Debris-Covered Glaciers
}

\author{
R. Sahu ${ }^{1, *}$ R. D. Gupta ${ }^{2}$ \\ ${ }^{1}$ GIS Cell, Motilal Nehru National Institute of Technology, Allahabad, India - rgi1503@mnnit.ac.in \\ ${ }^{2}$ Civil Engineering Department, Motilal Nehru National Institute of Technology, Allahabad, India - rdg@mnnit.ac.in
}

\author{
Commission V, SS: Natural Resources Management
}

KEY WORDS: Pixel-based classification, Object-based classification, Debris-covered glacier, Conceptual framework

\begin{abstract}
:
Delineation of the glacier is an important task for understanding response of glaciers to climate. In Himalayan region, most of the glaciers are covered with debris. Supraglacial debris works as an obstacle for automatic mapping of glacier using remote sensing data. Different methods have been used to reduce this difficulty based on pixel-based and object-based approaches using optical data, thermal data and DEM. Pixel-based glacier mapping is a traditional method for delineation of the glacier but the object-based method has emerged as a new approach in cryosphere application leading to its successful application in different applications. All pixel-based methods require some degree of manual correction because these can't be delineated automatically, especially in shadow area and debris covered part of the glacier. In the majority of studies, the object-based method has provided higher accuracy to delineate the debris-covered glacier. Spatially high spatial resolution satellite data is best suited for object-based image classification. In future, a combination of pixel-based method and object-based method can be attempted for delineation of the debris-covered glacier along with its critical analysis for suitability. The present paper critically reviews pixel-based and object-based methods as well as provides a framework for combined pixel and object-based method for delineation of debris-covered glacier.
\end{abstract}

\section{INTRODUCTION}

Mountain glaciers are an integral part of the cryosphere and constitute one of the most important feature of the Earth's natural systems (Scherler et al., 2011), specially Himalayan glacier which covers largest body of ice after the pole ice (Immerzeel, 2010). In last decades, global temperature increased due to climate change which directly affected the cryosphere in different parts of the world (Jian-ping et al., 2015; Nie et al., 2010; Racoviteanu et al., 2009). Mountainous and highland area (covered with ice) are highly sensitive to local climate change and are the amplifier for climate change for local region (Genxu et al., 2008) So glaciers are also a good indicator of climate change and experience recession due to climate change all over the world (Oerlemans 2005; Paul et al.,2007). Therefore, long-term glacier mapping is necessary to understand the behaviour of glaciers to climate change. For glacier mapping, a classical method is an in-situ measurement but this method is costly and large human efforts are required. Remote Sensing based methods have successfully been used for glacier mapping due to inaccessible glacier condition.

Debris-covered glaciers contain different types of material, i.e., snow, ice, water, and rock/debris, all these material flow slowly toward the terminus of glacier. These valley glaciers have varying amount of debris layer which constitutes dust, silt, sand, gravel, cobble and boulders in different parts of the world including the Himalayas (Bolch et al., 2008; Hambrey et al., 2008; Hewitt, 2005; Pratap et al., 2015; Shroder et al., 2000), the Andes (Racoviteanu et al., 2015) and the Alps (Paul et al., 2004). Mapping of the supraglacial is important because of its change due to the melting rate of ice up to $40 \%$ (Pratap et al., 2015). The assessment of debris part of the glacier is also important for study based on glacier mass balance, glacier runoff and glacier dynamics.

Different methods have been proposed to delineate glaciers using remote sensing data. Most of the methods are based on pixel-based approach and few on object-based approach. In the present paper, pixel-based methods and object-based methods are thoroughly and critically analysed. A new approach based on combined pixel and object-based methods has been suggested which will have the advantage of both pixel-based and object-based methods.

\section{DELINEATION OF GLACIERS USING PIXEL- BASED METHOD}

Delineation of glaciers is one of the main parameters to understand the behaviour of the glacier and to find out the mass-balance. To delineate the glaciers, generally, pixel-based methods have been used. In debris free part of the glacier, simple image ratio (Racoviteanu et al., 2009; Bolch et al., 2010a; Frey et al., 2012; Bhambri et al., 2013; Chand et al., 2015;) or Normalized Difference Snow Index(NDSI) (Keshri et al., 2009) has been used in pixel-based approach for automatic glacier mapping. The main hurdle in automatic glacier mapping

Corresponding author 
is supraglacial debris. Image ratio or NDSI alone can't distinguish supraglacial debris from surrounding moraine because reflectance remains same between Supraglacial debris and surrounding morain after applying NDSI or image ratio. Some extra information has been also used to delineate debris covered region of the glacier, i.e., thermal information, morphometric parameters (aspect, slope, plan, profile curvatures and elevation) derived from DEM.

Various authors have used these parameters in their study to delineate the glaciers. Paul et al. (2004) used multispectral satellite data and DEM by applying NDVI image ratio and hue whereas Bolch et al. (2007) used slope gradient, plane curvature and surface curvature information generated from ASTER DEM along with thermal data to delineate the debris-covered glacier. Bolch et al. (2007) also suggested that this method is promising in large glacier due to the low spatial resolution of ASTER DEM $(30 \mathrm{~m})$ but the availability of high-resolution DEM can render this method suitable for the small glacier.

Bishop et al. (1999) used Artificial Neural Network (ANN) for delineation of debris cover glacier and found that it performs well as compared to ISODATA algorithm. Shukla et al. (2010) used optical and thermal satellite data along with DEM derived geomorphometric parameters (i.e., aspect, slope, and elevation) in their study. Bhambri et al. (2011) proposed a semi-automatic method to classified debris-covered ice in glacier, in which they used a combination of slope and cluster data analysed using clustering algorithm coupled with thermal band thresholding. Karimi et al. (2012) also used optical and thermal data along with LiDAR DEM using supervised classification and found that this method performs well compared to the geomorphometric method. Racoviteanu and Williams (2012) proposed two methods, first is based on decision tree algorithm while second is based on texture analysis. Decision tree algorithm requires multispectral data, topographic variables such as surface reflectance, slope angle, elevation and kinetic temperature which was generated from ASTER bands 10 and 12. In texture analysis based method, co-occurrence measures, geostatistics, and filtering in spatial/ frequency domain based procedure is applied. Both methods have their own limitations.

Most of the algorithms are applied for a large area and these are not suitable for the small area. Bhardwaj et al.(2014) proposed methods which are implemented on two small glaciers, namely Hamtah and Patsio, having different elevation, climate condition and debris covered glacier area. Authors used optical and thermal data along with morphological parameter which was analysed by a clustering algorithm to delineate debriscovered glacier. Smith et al. (2015) used additional glacier surface velocity to filter low-velocity area (stable area). Bhardwaj et al. (2015) demonstrated Landsat 8 Operational Land Imager sensor-based method for automated mapping of glacier facies and supraglacial debris. Shukla and Ali (2016) developed a hierarchical knowledge-based classification algorithm for glacier mapping with particular emphasis on supraglacial debris (SGD), periglacial debris (PGD) and valley rock due to their spectral similarity. Some research works related to pixel-based method with salient characteristics are compiled in Table 1.

\section{DELINEATION OF GLACIERS USING OBJECT- BASED METHOD}

Object Based image analysis (OBIA) has emerged as a new approach for classification in the field of remote sensing.
Specially in last decade, use of object-based classification techniques in remote sensing has increased (Blaschke, 2010). To delineate the debris-covered glacier, OBIA techniques have been used in few studies (Robson et al., 2016). OBIA is based on Multi-Resolution Image Segmentation (MRIS) which is primarily used to segment an image at different resolution based on their spatial and spectral homogeneity (Rastner et al., 2014). Recently, the comparison between pixel based glacier mapping and OBIA based glacier mapping has been carried out in three glacier which have different challenging mapping conditions by Rastner et al. (2014). They have used optical and thermal data along with DEM to delineate the debris-covered glacier and achieved accuracy better than pixel-based approach, especially in debris-covered part.

Robson et al.(2015) proposed automatic classification method, which is based on an object-based algorithm and used optical, SAR and topographic data. They used SAR coherence data in the classification process. Robson et al. (2016) also proposed an algorithm based on optical data, thermal data, SAR data and LiDAR DEM. They also performed edge detection of the surface slope and also derived the profile curvature and hillshade model. Kraaijenbrink et al. (2016) demonstrated the use of OBIA to map and characterize geomorphical features on a debris-covered glacier using unmanned aerial vehicle imagery and DEM. The International Centre for Integrated Mountain Development (ICIMOD) has also used OBIA to estimate decade wise changes in Nepal and Bhutan and also to map glaciers over the entire Himalayas (Bajracharya et al., 2011; Bajracharya et al., 2014a,b). Eisank et al. (2010) used OBIA in the European Alps to delineate cirque glacier. Table 2 enlists salient works for delineation of debris-covered glaciers using OBIA.

\subsection{Multi-Resolution Image Segmentation (MRIS)}

Multi-Resolution Image segmentation is the main component of OBIA. MRIS have used before the classification defined in figure 1. Each segmented image is created by combining one or more criteria of homogeneity. Both spectral and spatial information is used in(Hay et al., 2008; van der Werff et al., 2008). Multi-resolution segmentation is a bottom-up approach and converts pixel into object based on their spatial and spectral homogeneity. MRIS becomes most important and critical stage in OBIA because selecting the value of input parameter is a complex and time consuming task (Dragut et al., 2014). To select the input parameter in MRIS is a crucial step as the accuracy of MRIS is highly dependent on input parameter 


\begin{tabular}{|c|c|c|c|c|c|}
\hline S. No. & Authors & Data used & Study area & $\begin{array}{l}\text { Reported } \\
\text { accuracy }\end{array}$ & Short description \\
\hline 1. & $\begin{array}{l}\text { Taschner and } \\
\text { Ranzi (2002) }\end{array}$ & Landsat, ASTER & Italian Alps & Not reported & $\begin{array}{l}\text { Delineation of clean ice using optical, thermal and } \\
\text { DEM }\end{array}$ \\
\hline 2. & \begin{tabular}{|l|} 
Paul et al. \\
$(2004)$
\end{tabular} & \begin{tabular}{|l|} 
Landsat, \\
ASTER-DEM \\
\end{tabular} & Swiss Alps & \begin{tabular}{|l|}
$21 \%$ of debris \\
misclassified \\
\end{tabular} & $\begin{array}{l}\text { Applying multispectral and DEM derived data for } \\
\text { delineation of clean ice using image ratio }\end{array}$ \\
\hline 3. & $\begin{array}{l}\text { Bolch et al. } \\
(2007)\end{array}$ & $\begin{array}{l}\text { ASTER, } \\
\text { ASTER-DEM }\end{array}$ & $\begin{array}{l}\text { Mt. Everest } \\
\text { region }\end{array}$ & $\begin{array}{l}5 \% \text { total area } \\
\text { misclassified }\end{array}$ & $\begin{array}{l}\text { Using morphological parameter derived from } \\
\text { DEM along with thermal data to delineate the } \\
\text { glacier }\end{array}$ \\
\hline 4. & $\begin{array}{l}\text { Shukla et al. } \\
(2010)\end{array}$ & $\begin{array}{l}\text { ASTER, } \\
\text { AWiFS, DEM }\end{array}$ & $\begin{array}{l}\text { SamudraTapu } \\
\text { Glacier, Himachal } \\
\text { Pradesh, India }\end{array}$ & $\begin{array}{l}8-14 \% \text { debris } \\
\text { misclassified }\end{array}$ & $\begin{array}{l}\text { Delineated the debris-covered glacier using } \\
\text { ASTER (optical and thermal) data coupled with } \\
\text { DEM }\end{array}$ \\
\hline 5. & $\begin{array}{l}\text { Bhambri et al. } \\
(2011)\end{array}$ & $\begin{array}{l}\text { ASTER, DEM, } \\
\text { Landsat, IRS } \\
\text { PAN } \\
\end{array}$ & $\begin{array}{l}\text { Gangotri } \\
\text { Glacier, Garhwal } \\
\text { Himalaya, India } \\
\end{array}$ & $\begin{array}{l}0.5-11 \% \\
\text { debris } \\
\text { misclassified }\end{array}$ & $\begin{array}{l}\text { Using DEM derived Slope and curvature } \\
\text { information using thermal band thresholding } \\
\text { coupled with a clustering algorithm }\end{array}$ \\
\hline 6. & $\begin{array}{l}\text { Racoviteanu } \\
\text { et al. (2012) }\end{array}$ & $\begin{array}{l}\text { ASTER, DEM, } \\
\text { Quickbird, } \\
\text { Worldview2 }\end{array}$ & $\begin{array}{l}\text { Sikkim Himalaya, } \\
\text { NE India }\end{array}$ & $\begin{array}{l}\text { (1) } 25 \% \\
\text { (2) } 31 \% \\
\text { debris } \\
\text { misclassified } \\
\end{array}$ & $\begin{array}{l}\text { Decision tree based classification using ASTER } \\
\text { data and topographic information, texture analysis } \\
\text { based on co-occurrence measures, geostatistics, } \\
\text { and filtering in spatial/frequency domain }\end{array}$ \\
\hline 7. & $\begin{array}{l}\text { Bhardwaj et } \\
\text { al. (2014) }\end{array}$ & $\begin{array}{l}\text { Landsat, } \\
\text { ASTER-DEM }\end{array}$ & $\begin{array}{l}\text { Hamtah, } \\
\text { Glacier,Patsio } \\
\text { Glacier }\end{array}$ & $\begin{array}{l}\text { Overall } \\
\text { accuracy is } \\
91 \% \text { in } \\
\text { Patsio Glacier }\end{array}$ & $\begin{array}{l}\text { Using threshold on optical, thermal data coupled } \\
\text { with slope and curvature data along with clustering } \\
\text { algorithm to delineate small debris-covered glacier }\end{array}$ \\
\hline 8. & $\begin{array}{l}\text { Ghosh et al. } \\
(2014)\end{array}$ & $\begin{array}{l}\text { Landsat images, } \\
\text { Cartosat-1 DEM }\end{array}$ & Pensilungpa glacier & $\begin{array}{l}86.29 \% \\
\text { accuracy }\end{array}$ & $\begin{array}{l}\text { Combining the results of slope, band ratio, IHS } \\
\text { transformation and supervised classification by } \\
\text { giving PCA data for mapping of supraglacial } \\
\text { debris covers }\end{array}$ \\
\hline 9. & $\begin{array}{l}\text { Alifu et al. } \\
(2015)\end{array}$ & Landsat images & $\begin{array}{l}\text { Koxkar glacier and } \\
\text { Yengisogatglacier, } \\
\text { China } \\
\end{array}$ & $\begin{array}{l}0.34-2 \% \\
\text { discrepancy }\end{array}$ & $\begin{array}{l}\text { New band ratio (TM6/(TM4/TM5)) and slope } \\
\text { information have been used to delineate debris- } \\
\text { covered glacier }\end{array}$ \\
\hline 10. & $\begin{array}{l}\text { Bhardwaj et } \\
\text { al.(2015) }\end{array}$ & \begin{tabular}{|l|} 
Landsat-8, \\
ASTER-DEM \\
\end{tabular} & \begin{tabular}{|l|} 
Shaune Garang \\
Glacier \\
\end{tabular} & Not reported & $\begin{array}{l}\text { Apply band ratio method on pan-sharpened } \\
\text { Landsat- } 8 \text { OLI band }\end{array}$ \\
\hline 11. & $\begin{array}{l}\text { Smith et al. } \\
(2015)\end{array}$ & $\begin{array}{l}\text { Landsat, SRTM } \\
\text { DEM, river } \\
\text { network }\end{array}$ & Pamir-Tien Shan & $\begin{array}{l}2-10 \% \text { total } \\
\text { area } \\
\text { misclassified }\end{array}$ & $\begin{array}{l}\text { Used glacier surface velocity and topographic } \\
\text { characteristics, improved by spectral and spatial } \\
\text { relationship data }\end{array}$ \\
\hline 12. & $\begin{array}{l}\text { Shukla et al. } \\
(2016)\end{array}$ & $\begin{array}{l}\text { ASTER,ASTER- } \\
\text { DEM }\end{array}$ & $\begin{array}{l}\text { Kolahoi } \\
\text { Glacier,Lidder } \\
\text { valley, western } \\
\text { Himalaya }\end{array}$ & $\begin{array}{l}\text { Over all } \\
\text { accuracy is } 89 \\
\%\end{array}$ & $\begin{array}{l}\text { Performed hierarchical knowledge-based } \\
\text { classification using a thermal mask, slope } \\
\text { information. and normalized-difference debris } \\
\text { index }\end{array}$ \\
\hline
\end{tabular}

Table 1. Pixel-based method to delineate debris-covered glacier

in MRIS (Rastner et al., 2014). Scale, size and compactness are the parameters which can be used as an input parameter in MRIS. Scale parameter defines the size of the object, size parameter controls the relative importance of the shape with colour/ pixel values, which is calculated by dividing the parameter by four times the square root of the area, whereas compactness parameter decides the compactness of resulting object and compactness refer as length and width divided by area (Dragut et al., 2014). Scale parameter is the main factor in MRIS which influences the final object highly (Blaschke, 2010) and also controls the internal (spectral) heterogeneity of object. The higher internal heterogeneity depends on the larger value of scale factor as result number of pixel per image-object increase (Dragut et al., 2014). All study based on OBIA for delineate the debris cover glacier show the higher accuracy as compared to pixel based approach.

\subsection{Analysis of Parameter Used in MRIS}

During the MRIS process, we have to carefully decide the value of scale, shape, and compactness. Value of parameters can be decided by hit and trail method which is time consuming (Rastner et al., 2014) or by automatic parameter selection algorithm (Robson et al., 2015). Dragut et al. (2014) developed automatic parameter selection method for MRIS. Different values for parameters were used in the delineation of debriscovered glacier which are compiled in Table 3.Rastner et al. (2014) used 10 as scale factor for few regions covered with debris and 20 for extensive debris covered areas. To delineate the debris-covered part of glacier for Manaslu region, Nepal, scale factor value 90 has been used (Robson et al., 2015) and 10 has been used for Hohe Tauern National park, Western Austria. 


\begin{tabular}{|c|c|c|c|c|c|}
\hline $\begin{array}{l}\text { S. } \\
\text { No. }\end{array}$ & Authors & Data used & Study area & Reported accuracy & Short description \\
\hline 1 & $\begin{array}{l}\text { Bajracharya } \\
\text { et al.(2011) }\end{array}$ & $\begin{array}{l}\text { Landsat MSS, } \\
\text { ETM+, and } \\
\text { SRTM DEM }\end{array}$ & $\begin{array}{l}\text { Hindu Kush- } \\
\text { Himalayan }\end{array}$ & Not reported & $\begin{array}{l}\text { used NDSI, NDVI, LWM (land and water } \\
\text { mask) slope, elevation, area coupled with } \\
\text { OBIA }\end{array}$ \\
\hline 2 & $\begin{array}{l}\text { Rastner et } \\
\text { al. (2013) }\end{array}$ & $\begin{array}{l}\text { ASTER, } \\
\text { Landsat, } \\
\text { DEM }\end{array}$ & $\begin{array}{l}\text { Three distinct } \\
\text { test regions }\end{array}$ & $\begin{array}{l}11.5 \% \text { (object-based) and } \\
23.4 \% \text { (pixel-based) areas for } \\
\text { Himalaya region }\end{array}$ & $\begin{array}{l}\text { used spectral and topographic } \\
\text { information to compare object-based and } \\
\text { pixel based approach }\end{array}$ \\
\hline 3 & $\begin{array}{l}\text { Bajracharya } \\
\text { et al. } \\
(2014 a)\end{array}$ & $\begin{array}{l}\text { Landsat MSS, } \\
\text { ETM+, and } \\
\text { SRTM DEM }\end{array}$ & Nepal Himalaya & $\begin{array}{l}\text { Uncertainty found to be } 2.6 \text {, } \\
1.3,1.6 \text { and } 1.6 \% \text { for } 1980, \\
\text { 1990, 2000, and } 2010 \\
\text { respectively. }\end{array}$ & $\begin{array}{l}\text { Used NDSI, NDVI, LWM (land and water } \\
\text { mask) slope, elevation, area coupled with } \\
\text { OBIA }\end{array}$ \\
\hline 4 & $\begin{array}{l}\text { Bajracharya } \\
\text { et } \\
\text { al. }(2014 b)\end{array}$ & $\begin{array}{l}\text { Landsat MSS, } \\
\text { ETM+ and } \\
\text { SRTM DEM }\end{array}$ & Bhutan & $\begin{array}{l}\text { Uncertainty found to be } 3.4 \% \text {, } \\
2.5 \%, 2.4 \% \text { and } 2.5 \% \text { for the } \\
\text { years } 1980,1990,2000 \text { and } \\
2010 \text { respectively. }\end{array}$ & $\begin{array}{l}\text { Used NDSI, NDVI, LWM (land and water } \\
\text { mask) slope, elevation, area, coupled with } \\
\text { OBIA approach }\end{array}$ \\
\hline 5 & $\begin{array}{l}\text { Robson et } \\
\text { al. (2015) }\end{array}$ & $\begin{array}{l}\text { Landsat- } \\
\text { 8,SRTM } \\
\text { DEM,ALOS } \\
\text { PALSAR } \\
\end{array}$ & $\begin{array}{l}\text { Manaslu region } \\
\text { of Nepal }\end{array}$ & overall accuracy is $91 \%$ & $\begin{array}{l}\text { OBIA using Landsat and ALOS PALSAR } \\
\text { data coupled with DEM }\end{array}$ \\
\hline 6 & $\begin{array}{l}\text { Kraaijenbrin } \\
\text { k et al. } \\
(2016) \\
\end{array}$ & $\begin{array}{l}\text { Unmanned } \\
\text { aerial vehicle } \\
\text { imagery } \\
\end{array}$ & $\begin{array}{l}\text { Langtang Glacier, } \\
\text { Nepalese } \\
\text { Himalaya } \\
\end{array}$ & Not reported & $\begin{array}{l}\text { Multiple feature categories in debris- } \\
\text { covered glacier using OBIA and used } \\
\text { nearest neighbour classifier }\end{array}$ \\
\hline 7 & $\begin{array}{l}\text { Nijhawan et } \\
\text { al. (2016) }\end{array}$ & $\begin{array}{l}\text { Landsat } \\
\text { image }\end{array}$ & $\begin{array}{l}\text { Part of } \\
\text { Alaknanda basin }\end{array}$ & $\begin{array}{l}\text { not reported, OBIA more } \\
\text { efficient compared } \\
\text { to sub pixel-based and } \\
\text { supervised classification } \\
\end{array}$ & $\begin{array}{l}\text { Compared Object-based, sub-pixel based } \\
\text { and supervised classification using } \\
\text { multispectral data }\end{array}$ \\
\hline 8 & $\begin{array}{l}\text { Robson et } \\
\text { al. (2016) }\end{array}$ & $\begin{array}{l}\text { Landsat, } \\
\text { LiDAR DEM, } \\
\text { SRTM DEM, } \\
\text { ALOS } \\
\text { PALSAR } \\
\end{array}$ & $\begin{array}{l}\text { Hohe Tauern } \\
\text { National, Park } \\
\text { (HTNP), western } \\
\text { Austria }\end{array}$ & $\begin{array}{l}\text { Overall accuracy found to be } \\
94 \%\end{array}$ & $\begin{array}{l}\text { Used spectral, SAR and LiDAR DEM data } \\
\text { coupled with OBIA }\end{array}$ \\
\hline
\end{tabular}

Table 2. OBIA for delineation of debris-covered glaciers

Kraaijenbrink et al., (2016) have used 500 in scale factor for Langtang Glacier (Nepal) but the resolution of input image was $0.5 \mathrm{~m}$.

\section{ADVANTAGE AND DISADVANTAGES OF PIXEL- BASED APPROACH AND OBIA BASED APPROACH}

Pixel-based approach has some advantage over OBIA approach. Pixel-based approach show lower sensitivity to the selection of threshold values of the different parameter during classification. The computational cost in pixel based approach is less as compared to object-based approach (Rastner et al., 2014). Using pixel based approach, larger size glacier mapping is possible using several satellite images in one step after mosaicking. Along with these advantages, pixel based approach has several disadvantages. The biggest disadvantage is their limited post processing capabilities (Jawak et al., 2015). Pixel-based approach has no capabilities to develop the relationship between the pixel and surrounding pixels. The final result of mapping highly depends on initial input parameter i.e. DEM. Pixel-based remote sensing classification also has poor transferability such as maximum likelihood or ISODATA

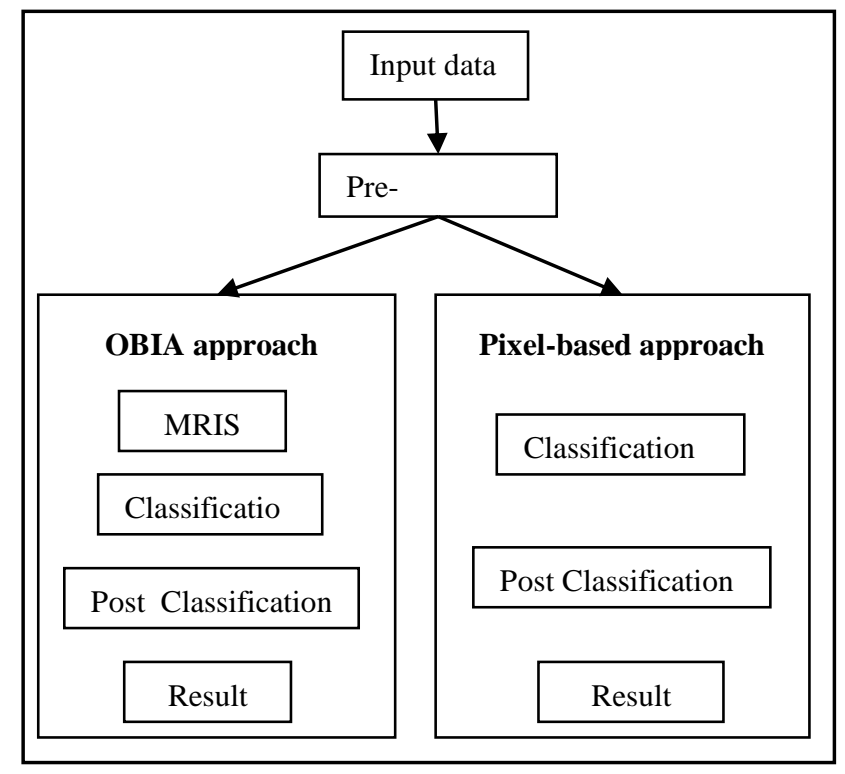

Figure 1. Flow chart of Object based approach and Pixel-based approach classification 


\begin{tabular}{|c|c|c|c|c|c|c|}
\hline & Author & Region & scale & Shape & compactness & Level \\
\hline \multirow{3}{*}{1} & \multirow{3}{*}{$\begin{array}{l}\text { Rastner et al., } \\
(2014)\end{array}$} & Watkins range/Greenland & 10 & 0.1 & 0.5 & 3 \\
\hline & & Everest (Himalaya) & 20 & 0.1 & 0.5 & 3 \\
\hline & & Coast Mountain Canada & 20 & 0.1 & 0.5 & 3 \\
\hline \multirow{3}{*}{2} & \multirow{3}{*}{$\begin{array}{l}\text { Robson et al., } \\
\text { (2015) }\end{array}$} & Manaslu region (Nepal) & 20 & 0.3 & 0.6 & 1 \\
\hline & & Manaslu region (Nepal) & 55 & 0.3 & 0.6 & 2 \\
\hline & & Manaslu region (Nepal) & 90 & 0.3 & 0.6 & 3 \\
\hline \multirow{3}{*}{3} & \multirow{3}{*}{$\begin{array}{l}\text { Robson et al., } \\
(2016)\end{array}$} & $\begin{array}{l}\text { Hohe Tauern National Park } \\
\text { (Western Austria) }\end{array}$ & $3(5)$ & 0.3 & 0.6 & 1 \\
\hline & & $\begin{array}{l}\text { Hohe Tauern National Park } \\
\text { (Western Ausria) }\end{array}$ & $5(8)$ & 0.8 & 0.6 & 2 \\
\hline & & $\begin{array}{l}\text { Hohe Tauern National Park } \\
\text { (Western Ausria) }\end{array}$ & $10(12)$ & 0.25 & 0.5 & 3 \\
\hline 4 & $\begin{array}{l}\text { Kraaijenbrink } \\
\text { et al., (2016) }\end{array}$ & Langtang Glacier (Nepal) & 500 & 0.4 & 0.5 & $\begin{array}{c}\text { Not } \\
\text { defined }\end{array}$ \\
\hline
\end{tabular}

Table 3. Analysis of parameter used in MRIS

clustering but image ratio methods are an exception as they are robust (Racoviteanu et al., 2009).

OBIA approach has a number of advantages in cryosphere application for glacier mapping. OBIA gives higher accuracy as compared to pixel-based approach for glacier mapping due to its initial high weighting of auxiliary data such as slope and brightness temperature (Rastner et al., 2014; Robson et al., 2015; Robson et al., 2016). Neighbour-based classification rules or the use of fuzzy rules, involved in OBIA approach are less dependent on input parameters (image, slope and temperature information) (Blaschke, 2010; Flanders et al., 2003). Having these advantages, OBIA approach has some disadvantages (Rastner et al., 2014). OBIA approach is highly dependent on initial segmentation for mapping accuracy. Computation cost is also high and takes large virtual memory allocation. During the image segmentation, two errors generally occur, namely, under segmentation and over segmentation (Blaschke, 2010). The main advantage of OBIA approach is their post-processing capabilities i.e. Loop, neighbourhood relationships shape dependent classification procedure (Aubrey et al., 2015). OBIA approach has high transferability and robustness because features involved in OBIA approach are less dependent on input parameters (Blaschke, 2010; Flanders et al., 2003).

\section{PARAMETERS AFFECTING DELINEATION OF DEBRIS COVERED GLACIER}

During the glacier mapping, several factors affect its accuracy i.e. DEM, shadow on glacier, supraglacial debris (SGD), periglacial debris (PGD (Shukla and Ali, 2016). Several studies suggest their limitation to delineate small glacier due to the low resolution of DEM. They suggested that high-resolution DEM will play a crucial role to delineate the small debris cover glacier because of the morphological parameters derived from DEM. Bhardwaj et al. (2014) focussed on problem which occurred during the classification, including the parameters like seasonal

snow cover, variation in light conditions and satellite bandwidth variations. At a particular point on Earth, elevation angle of sun changes with respect to time, which leads to different light condition and thus shadows. The biggest problem in Glacier mapping is to separate the SGD from PGD. Both SGD and PGD give the same spectral response but temperature difference exists between SGD and PGD (Shukla et al., 2010).

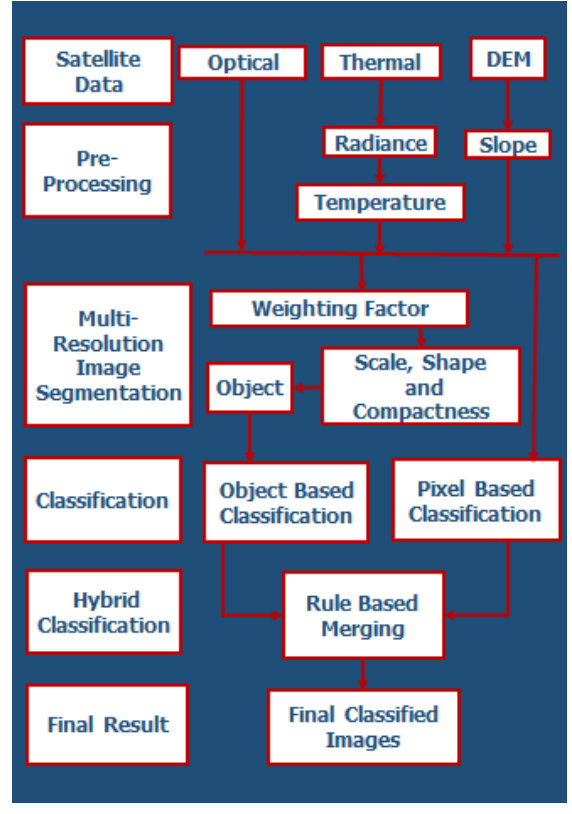

Figure 2. Flow chart of combined pixel and Object based classification

\section{NEW POSSIBILITIES FOR MAPPING DEBRIS COVERED GLACIER}

To delineate glacier, many pixel-based and few OBIA approaches have been used. Both approaches have their own advantages and disadvantages. The combination of both pixelbased and OBIA approach has not been used in cryosphere application. However, combined pixel-based and object-based method has successful been used in others application except for cryosphere. Wang (2004) proposed maximum likelihood classification at the pixel level followed by nearest neighbour object based classification. Aguirre-Gutiérrez et al. (2012) separately classified satellite image using pixel-based and OBIA approach and selected the class which gives the best result of both methods. Huang and Zhang, (2014) proposed a novel decision-level probability fusion based multi-level classification method by combining pixel-based structural features and objectbased shape features. Zhang et al. (2013) performed OBIA classification on pixel-level classification and segmented the image based on majority voting method. Brik et al. (2013) proposed an efficient framework by instigating pixel and objectbased approaches for image classification using Support Vector 
Machines (SVMs) and Dempster-Shafer Theory of Evidence (DSTE). Liao et al., (2014) used feature based fusion method to couple dimension reduction and data fusion of the pixel and object-based features using hyperspectral images. Li and Wan (2015) used new combination classification of pixel and objectbased methods applying pixel-based classification to correct the object based classification result. Thus, the combination of pixel-based and OBIA based approach has been successfully used in above literature. Therefore, there is need of testing the efficacy of combination of pixel-based and OBIA approach in cryosphere also because this type of combination has already been used in other application successfully.

The flow chart showing the proposed methodology for new framework of combined pixel-based and object-based method for delineation of the debris-covered glacier is given in figure 2 . In OBIA method, morphological parameters e.g. plane curvature, profile curvature etc. have never been used which have already been successfully used in pixel based approach. In the proposed approach, it is planned to first apply OBIA and pixel-based approach separately, followed by merging the both based on different rule set. These rules can be generated based on type of features available in the study area, resolution of image, threshold values, etc. After this, final classified image will be generated.

\section{DISCUSSTION AND CONCLUSION}

Delineation of the debris-covered glacier can be done by two approaches i.e. pixel-based and OBIA based. The classical method is a pixel-based approach which has been used in most of the studies. This approach generally uses thermal, topographic and morphological data to distinguee SDG from PDG but it has limitation i.e. no utilization of nearer pixel information. The OBIA has recently been used in delineation of debris-covered glacier and uses information of nearer pixel for a final decision. OBIA approach also has post-processing capabilities which is not present in pixel-based approach.

Combined pixel-based and OBIA approach has the potential to become a new approach for delineation of the debris-covered glacier which has already been used successfully in other studies. A conceptual framework for combined pixel and object based classification approach for delineation of debris cover glacier is presented in this paper. The application of the proposed approach for a field problem is ongoing and the results shall be presented for publication in subsequent research paper.

\section{REFERENCES}

Aguirre-Gutiérrez, J., Seijmonsbergen, A.C., and Duivenvoorden, J.F., 2012. Optimizing land cover classi fi cation accuracy for change detection, a combined pixel-based and object-based approach in a mountainous area in Mexico. Appl. Geogr. 34, pp.29-37.

Alifu, H., Tateishi, R., and Johnson, B., 2015. A new band ratio technique for mapping debris-covered glaciers using Landsat imagery and a digital elevation model. Int. J. Remote Sens. 36(8), pp.2063-2075.

Aubrey, B., Nuth, C., Olaf, S., Hölbling, D., Strozzi, T., and Ringkjøb, P., 2015. Automated classi fi cation of debriscovered glaciers combining optical, SAR and topographic data in an object-based environment. Remote Sens. Environ. 170, pp.372-387.

Bajracharya, S.R., Maharjan, S.B., Shrestha, F., Bajracharya, O.R., and Baidya, S.K., 2014a. Glacier Status in Nepal and Decadal Change from 1980 to 2010 Based on Landsat Data. Kathmandu, Nepal ICIMOD.

Bajracharya, S.R., and Shrestha, B., 2011. The Status of Glaciers in the Hindu Kush-Himalayan Region. Kathmandu, Nepal,ICIMOD.

Bajracharya, S.R., and Shrestha, F., 2014b. The status and decadal change of glaciers in Bhutan from 1980s to 2010 based on the satellite data. Ann. Glaciol. 55(66), pp.159-166.

Bhambri, R., Bolch, T., Chaujar, R.K., Taylor, P., Bhambri, R., and Bolch, T., 2011. Mapping of debris-covered glaciers in the Garhwal Himalayas using ASTER DEMs and thermal data. Int. J. Remote Sens. 32(23), pp.8095-8119.

Bhardwaj, A., Joshi, P.K., Snehmani, Sam, L., Singh, M.K., Singh, S., and Kumar, R., 2015. Applicability of Landsat 8 data for characterizing glacier facies and supraglacial debris. Int. J. Appl. Earth Obs. Geoinf. 38, pp.51-64.

Bhardwaj, A., Joshi, P.K., Snehmani, Singh, M.K., Sam, L., and Gupta, R.D., 2014. Mapping debris-covered glaciers and identifying factors affecting the accuracy. Cold Reg. Sci. Technol. 106-107, pp.161-174.

Bishop, M.P., Shroder, J.F., and Hickman, B.L., 1999. SPOT Panchromatic Imagery and Neural Networks for Information Extraction in a Complex Mountain Environment. Geocarto Int. 14(2), pp.19-28.

Blaschke, T., 2010. ISPRS Journal of Photogrammetry and Remote Sensing Object based image analysis for remote sensing 65 , pp. $2-16$.

Blaschke, T., 2001. What's wrong with pixels? Some recent developments interfacing remote sensing and GIS. Interfacing Remote Sens. GIS.

Bolch, T., Buchroithner, M., Kunert, A., and Kamp, U., 2007. Automated Delineation of Debris-Covered Glaciers Based on ASTER Data. Geoinf. Eur. (Proc. 27th EARSel Symp. 04-07 June 2007), Bozen, Italy. (June), pp.403-410.

Bolch, T., Buchroithner, M., Pieczonka, T., and Kunert, A., 2008. Planimetric and volumetric glacier changes in the Khumbu Himal, Nepal, since 1962 using Corona, Landsat TM and ASTER data. J. Glaciol. 54(187), pp.592-600.

Brik, Y., Zerrouki, N., and Bouchaffra, D., 2013. Combining pixel- and object-based approaches for multispectral image classification using dempster-shafer theory, in: Proceedings 2013 International Conference on Signal-Image Technology and Internet-Based Systems, SITIS 2013. pp. 448-453.

Dragut, L., Csillik, O., Eisank, C., and Tiede, D., 2014. Automated parameterisation for multi-scale image segmentation on multiple layers. ISPRS J. Photogramm. Remote Sens. 88, pp.119-127. 
Eisank, C., Drăguţ, L., GOtz, J., and Blaschke, T., 2010. Devloping a Semantic Model of Glacial Landforms for ObjectBased Terrain Classification - The Example of Glacial Cirques. Int. Arch. Photogramm. Remote Sens. Spat. Inf. Sci. 38(4/c7).

Flanders, D., Hall-beyer, M., and Pereverzoff, J., 2003. Technical Note / Note technique Preliminary evaluation of eCognition object-based software for cut block delineation and feature extraction 29(4), pp.441-452.

Genxu, W., Yuanshou, L., Yibo, W., and Qingbo, W., 2008. Effects of permafrost thawing on vegetation and soil carbon pool losses on the Qinghai-Tibet Plateau, China. Geoderma 143, pp.143-152.

Ghosh, S., Pandey, A.C., and Nathawat, M.S., 2014. Mapping of debris-covered glaciers in parts of the Greater Himalaya Range, Ladakh, western Himalaya , using remote sensing and GIS. J. Appl. Remote Sens. 8, pp.1-17.

Hambrey, M.J., Quincey, D.J., Glasser, N.F., Reynolds, J.M., Richardson, S.J., and Clemmens, S., 2008. Sedimentological, geomorphological and dynamic context of debris-mantled glaciers, Mount Everest (Sagarmatha) region, Nepal. Quat. Sci. Rev. 27, pp.2361-2389.

Hay, G.J., and Castilla, G., 2008. Geographic Object-Based Image Analysis (GEOBIA): A new name for a new discipline, in: Blaschke, T., Lang, S., Hay, G. (Eds.), Object-Based Image Analysis Spatial Concepts for Knowledge-Driven Remote Sensing Applications. Lecture Notes in Geoinformation and Cartography, Springer, Berlin, Heidelberg, pp. 75-89.

Hewitt, K., 2005. The Karakoram Anomaly? Glacier Expansion and the "Elevation Effect ," Karakoram Himalaya. Geogr. Environ. Stud. Fac. Publ. 8.

Hoelzle, M., Chinn, T., Stumm, D., Paul, F., Zemp, M., and Haeberli, W., 2007. The application of glacier inventory data for estimating past climate change effects on mountain glaciers: A comparison between the European Alps and the Southern Alps of New Zealand. Glob. Planet. Change 56, pp.69-82.

Huang, X., and Zhang, L., 2014. A multievel decision fusion approach for urban mapping using very high- resolution multi / hyperspectral imagery. Int. J. Remote Sens. 33(11), pp.37-41.

Immerzeel, W.W., 2010. Climate Change Will Affect the Asian Water Towers 328, pp.1382-1385.

Jawak, S.D., Devliyal, P., and Luis, A.J., 2015. A Comprehensive Review on Pixel Oriented and Object Oriented Methods for Information Extraction from Remotely Sensed Satellite Images with a Special Emphasis on Cryospheric Application. Adv. Remote Sens. 4, pp.177-195.

Jian-ping, Y., Yong-jian, D., Shi-yin, L.I.U., and Chun-ping, T.A.N., 2015. Vulnerability of mountain glaciers in China to climate change. Adv. Clim. Chang. Res. 6, pp.171-180.

Karimi, N., Farokhnia, A., Karimi, L., Eftekhari, M., and Ghalkhani, H., 2012. Combining optical and thermal remote sensing data for mapping debris-covered glaciers (Alamkouh Glaciers, Iran). Cold Reg. Sci. Technol. 71(January), pp.73-83.
Keshri, A.K., Shukla, A., and Gupta, R.P., 2009. ASTER ratio indices for supraglacial terrain mapping. Int. J. Remote Sens. 30(2), pp.519-524.

Kraaijenbrink, P.D.A., Shea, J.M., Pellicciotti, F., Jong, S.M. De, and Immerzeel, W.W., 2016. Remote Sensing of Environment Object-based analysis of unmanned aerial vehicle imagery to map and characterise surface features on a debriscovered glacier. Remote Sens. Environ. 186, pp.581-595.

Li, G., and Wan, Y., 2015. A new combination classification of pixel- and object-based methods. Int. J. Remote Sens. 36(23), pp.5842-5868.

Liao, W., Coillie, F. Van, Devriendt, F., Gautama, S., and Pizurica, A., 2014. Fusion of pixel - based and object - based features for classification of urban hyperspectral remote sensing data. South-Eastern Eur. J. Earth Obs. Geomatics Issue 3(2S), pp.179-183.

Nie, Y., Zhang, Y., Liu, L., and Zhang, J., 2010. Glacial change in the vicinity of Mt. Qomolangma (Everest), central high Himalayas since 1976. J. Geogr. Sci. 20(5), pp.667-686.

Nijhawan, R., Garg, P., and Thakur, P., 2016. A comparison of classification techniques for glacier change detection using multispectral images. Perspect. Sci. (in Press. 8, pp.377-380.

Oerlemans, J., 2005. Extracting a climate signal from 169 glacier records. Science 308, pp.675-677.

Paul, F., Huggel, C., and Kääb, A., 2004. Combining satellite multispectral image data and a digital elevation model for mapping debris-covered glaciers. Remote Sens. Environ. 89, pp.510-518.

Paul, F., Kääb, A., and Haeberli, W., 2007. Recent glacier changes in the Alps observed by satellite: Consequences for future monitoring strategies. Glob. Planet. Change 56, pp.111122.

Pratap, B., Dobhal, D.P., Mehta, M., and Bhambri, R., 2015. Influence of debris cover and altitude on glacier surface melting: a case study on Dokriani Glacier, central Himalaya, India. Ann. Glaciol. 56(70), pp.9-16.

Racoviteanu, A., and Williams, M.W., 2012. Decision tree and texture analysis for mapping debris-covered glaciers in the Kangchenjunga area, eastern Himalaya. Remote Sens. 4, pp.3078-3109.

Racoviteanu, A.E., Arnaud, Y., Williams, M.W., and Manley, W.F., 2015. Spatial patterns in glacier characteristics and area changes from 1962 to 2006 in the Kanchenjunga-Sikkim area, eastern Himalaya. Cryosphere 9(2), pp.505-523.

Racoviteanu, A.E., Paul, F., Raup, B., Jodha, S., Khalsa, S., and Armstrong, R., 2009. Challenges and recommendations in mapping of glacier parameters from space : results of the 2008 Global Land Ice Measurements from Space ( GLIMS ) workshop , Boulder, Colorado , USA. Ann. Glaciol. 50(53), pp.53-69.

Rastner, P., Bolch, T., Notarnicola, C., and Paul, F., 2014. A 
comparison of pixel- and object-based glacier classification with optical satellite images. IEEE J. Sel. Top. Appl. Earth Obs. Remote Sens. 7(3), pp.984-993.

Robson, B.A., Hölbling, D., Nuth, C., Strozzi, T., and Dahl, S.O., 2016. Decadal scale changes in Glacier area in the Hohe Tauern national park (Austria) determined by object-based image analysis. Remote Sens. 8(67), pp.1-23.

Scherler, D., Bookhagen, B., and Strecker, M.R., 2011. Spatially variable response of Himalayan glaciers to climate change affected by debris cover. Nat. Geosci. 4(3), pp.156-159.

Shroder, J.F., Shroder, J.F., Bishop, M.P., Bishop, M.P., Copland, L., Copland, L., Sloan, V.F., and Sloan, V.F., 2000. Debris-covered glaciers and rock glaciers in the nanga parbat himalaya, pakistan. Geogr. Ann. 82(A), pp.17-31.

Shukla, A., and Ali, I., 2016. A hierarchical knowledge-based classification for glacier terrain mapping: A case study from Kolahoi Glacier, Kashmir Himalaya. Ann. Glaciol. 57(71), pp.1-10.

Shukla, A., Arora, M.K., and Gupta, R.P., 2010. Synergistic approach for mapping debris-covered glaciers using opticalthermal remote sensing data with inputs from geomorphometric parameters. Remote Sens. Environ. 114(7), pp.1378-1387.

Smith, T., Bookhagen, B., and Cannon, F., 2015. Improving semi-automated glacier mapping with a multi-method approach: Applications in central Asia. Cryosphere 9(5), pp.1747-1759.

Taschner, S., and Ranzi, R., 2002. Comparing the opportunities of Landsat-TM and Aster data for monitoring a debris covered glacier in the Italian Alps within the GLIMS project. IEEE Int. Geosci. Remote Sens. Symp. 2, pp.1044-46.

van der Werff, H.M.A., and van der Meer, F.D., 2008. Shapebased classification of spectrally identical objects. ISPRS J. Photogramm. Remote Sens. 63, pp.251-258.

Wang, L., 2004. Integration of object-based and pixel-based classification for mapping mangroves with IKONOS imagery. Int. J. Remote Sens. 25(24), pp.5655-5668.

Zhang, Q., Huang, X., and Zhang, L., 2013. An Energy-Driven Total Variation Model for Segmentation and Classification of High Spatial Resolution Remote-Sensing Imagery. IEEE Int. Geosci. Remote Sens. Lett. 10(1), pp.125-129. 